\title{
Új terápiás célpont akut myeloid leukémiában: izocitrát dehidrogenáz 1 és 2 mutációk
}

\author{
Kövy Petra ${ }^{1,2}$, Kozma András ${ }^{1}$, Bors András ${ }^{1}$, Meggyesi Nóra ${ }^{1}$, Ádám Emma ${ }^{1}$, \\ Borsy Adrienn' ${ }^{1}$, Dolgos János ${ }^{3}$, Lovas Nóra ${ }^{3}$, Harasztdombi József ${ }^{3}$, Lakatos Viktor ${ }^{3}$, \\ Vályi-Nagy István ${ }^{3}$, Mikala Gábor ${ }^{3}$, Reményi Péter ${ }^{3}$, Andrikovics Hajnalka ${ }^{1 @}$ \\ ${ }^{1}$ Dél-pesti Centrumkórház, Országos Hematológiai és Infektológiai Intézet, \\ Molekuláris Genetikai Laboratórium, Budapest \\ ${ }^{2}$ Rácz Károly Doktori Iskola, Semmelweis Egyetem, Budapest \\ ${ }^{3}$ Dél-pesti Centrumkórház, Országos Hematológiai és Infektológiai Intézet, \\ Hematológiai és Őssejt-transzplantációs Osztály, Budapest
}

\begin{abstract}
Az izocitrát dehidrogenáz 1 és 2 szomatikus mutációk az akut myeloid leukémia visszatérő genetikai eltérései, tágabb értelemben vett epigenetikus hatásmóddal. Az irodalomban ellentmondó adatok szerepelnek arra vonatkozóan, hogy e szerzett genetikai eltérések pre-leukémiás, leukémia alapító vagy domináns klónban alakulnak ki.

Tanulmányunk célja az izocitrát dehidrogenáz 1 és 2 mutációk gyakoriságának, egyéb genetikai eltérésekkel való társulásának, illetve a diagnózis és szusminta párokban észlelt stabilitásának vizsgálata akut myeloid leukémiában.

A vizsgálatba 2001-2018 közưr ritézményünkben konszekutívan diagnosztizált és kezelt 748 akut myeloid leukémiában szenvedő beteget vontunk be. A mutációk vizsgálata komplex algoritmus szerint történt, olvadásigörbe-analízissel, allélspecifikus polimeráz-láncreakcióval és Sanger-szekvenálással.

A betegek 8,6\%-a (64/748) rendelkezett izocitrát dehidrogenáz 1 mutációval és 11\%-a (82/748) izocitrát dehidrogenáz Ditációval. Mindkét mutáció főként normál kariotípussal társult $(58,3 \%, p=0,0135 ; 58,1 \% p=0,006)$ a mutációnegatíranoz (39,3\%) képest. Az izocitrát dehidrogenáz 1 mutációk 52,4\%-a $(p<0,001)$, az izocitrát dehidrogenáz 2 mutációk 39\%-a ( $p<0,001$ (10) eophosminmutációval együtt fordult elő (a mutációnegatív betegekhez képest: 2 (3). Az izocitrát dehidrogenáz 1 nrưa ió 96,2\%-ban (102/106), az izocitrát(d) drogenáz 2 97,4\%-ban (111/114) stabilanturen volt a diagnózisos és relapszusos mintapárokban.

Vizsgálataink megerősítették, hogy az izocitrát dehidrogenáz mutációk az akut myeloid leukémia leggyakoribb genetikai eltérései közé tartoznak (19,5\%). A mutációk stabil jelenléte a diagnózis és relapszusminta párokban a mutáció korai kialakulását sugallja (pre-leukémiás vagy émiaalapító). Ezek a megfigyelések hangsúlyozzák az izocitrát dehidrogenáz

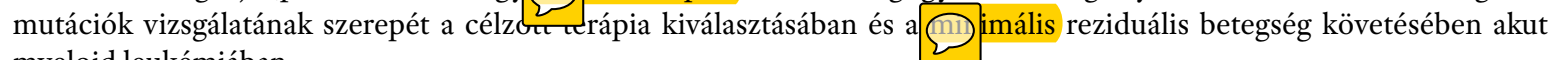
myeloid leukémiában.
\end{abstract}

Kulcsszavak: izocitrát dehidrogenáz 1 és 2, akut myeloid leukémia, nucleophosmin 1, citogenetika

\section{Novel therapeutic target in acute myeloid leukaemia: isocitrate dehydrogenase 1 and 2 mutations}

Somatic mutations in isocitrate dehydrogenase $1 \& 2$ are recurrent genetic alterations in acute myeloid leukaemia causing epigenetic alterations. In the literature, contradictory data has been accumulated, whether these acquired genetic lesions represent pre-leukemic (C) aemia-founder or dominant clone mutations.

The aims of our study wer investigate i) the frequency ii) the associations with other genetic alterations, and iii) the stability at diagnosis and relapse of isocitrate dehydrogenase $1 \& 2$ mutations in acute myeloid leukaemia.

Patients $(n=748)$ consecutively diagnosed with acute myeloid leukaemia between 2001-2018 in our Institute were enrolled in our study. Mutations were tested by complex diagnostic algorithm with 1 -resolution melting, allele-
specific polymerase chain reaction and Sanger-sequencing.

Isocitrate dehydrogenase 1 mutations occurred in $8.6 \%(64 / 748)$ and isocitrate dehydrogenase 2 mutations in $11 \%$ $(82 / 748)$ of cases. Both mutations were associated with normal karyotype $(58.3 \%, p=0.0135 ; 58.1 \% p=0.006$, respec-

@ Levelezési cím: Andrikovics Hajnalka, Dél-pesti Centrumkórház, Országos Hematológiai és Infektológiai Intézet, Molekuláris Genetikai Laboratórium, 1097 Budapest, Albert Flórián utca 5-7.; Tel.: +36-1-219-6188; E-mail: andrikovics.hajnalka@dpckorhaz.hu 
tively) versus mutation-negatives $(39.3 \%)$. Similar co-occurrence was observed with nucleophosmin 1 mutation [52.4\% $(p<0.001)$ and 39\% $(p<0.001)$ versus mutation-negative cases $(24.3 \%)$ ]. Isocitrate dehydrogenase 1 mutation was constantly present in 96.2\% (102/106), isocitrate dehydrogenase 2 in 97.4\% (111/114) of (10) nosis/relapse sample pairs.

Our study confirmed that isocitrate dehydrogenase mutations are among the most frequent genetic alterations in acute myeloid leukaemia (19.5\%). The stabile presentations of the mutations in diagnosis and relapse sample pairs suggest an early development of these genetic alterations (preleukemic or leukaemia-founder). These observations strengthen the role of isocitrate dehydrogenase mutations testing in choosing targeted therapy and monitoring measurable residual disease in acute myeloid leukaemia.

Keywords: isocitrate dehidrogenase 1\&2, acute myeloid leukaemia, nucleophosmin 1, cytogenetics

(Beérkezett: 2018. március 22.; elfogadva: 2019. június 13.)

\section{Rövidítések}

aKG $=$ a-ketoglutarát; AML = akut myeloid leukémia; BCL-2 = B sejt CLL/lymphoma; CEBPA = CCAAT/enhancer-binding protein alpha; $\mathrm{COX}=$ citokróm $\mathrm{C}$ oxidáz; $\mathrm{CR}=$ komplett remisszió; DNMT3A = DNS (citozin-5) metiltranszferáz 3A; ELN = Európai Leukémia Net; ESZSZK = Egyesített Szent István és Szent László Kórház; FDA = Food and Drug Administration; FISH = fluoreszcens in situ hibridizáció; FLT3-ITD = fms-like tirozin kináz internál tandem duplikáció; FLT3-TKD = fms-like tirozin kináz-tirozin kináz domén mutáció; GATA1 = GATA-binding factor 1 ; 2-HG = 2-hydroxyglutarát; HMA = hypometiláló szerek; HRM = high resolution melting; IDH = izocitrát dehidrogenáz; IDH1 = izocitrát dehidrogenáz 1; IDH2 = izocitrát dehidrogenáz 2; MDS = myelodiszpláziás szindróma; $\mathrm{MPN}=$ myeloproliferatív neoplázia; MRD = (mális reziduális betegség; $\mathrm{NK}=$ normál kariotípus; NPM1 = nucleophosmin 1; NRAS = NRAS proto-onkogén; OGYK = Országos Gyógyintézeti Központ; OHII = Országos Hematológiai és Immunológiai Intézet; ORR = overall response rate; $\mathrm{PCR}=$ polimeráz-láncreakció; $\mathrm{R} 132(\mathrm{C} / \mathrm{H} / \mathrm{S} / \mathrm{P} / \mathrm{G} / \mathrm{L})=132$-es $\operatorname{arginin}$ aminosavcserével járó mutáció (cisztein/hisztidin/szerin/ prolin/glicin/leucin); R140Q $=140$-es arginin glutamincserével járó mutáció; R172K = 172-es arginin lizincserével járó mutáció; $\mathrm{R} / \mathrm{R}$ = relabált és refrakter; $\mathrm{RUNX1}=$ Runt-related transcription factor 1 ; TET2 $=$ Tet metilcitozin dioxigenáz 2

Az izocitrát dehidrogenázok (IDH) homodimer katalitikus enzimek, amelyek a citromsav- (Szent-GyörgyiKrebs-) ciklusban és kapcsolódó metabolikus útvonalakban vesznek részt. Az IDH1 és IDH2 gének a 2q34 és a 15q26 kromoszómarégióban helyezkednek el. Az IDH1 enzim a citoszolban, az IDH2 a mitokondriumban található $[1,2]$. Mindkét enzim a citrátkör második irrever- zibilis lépését, az izocitrá @etoglutarát átalakulását képes katalizálni. IDH1 és I1 Hz funkciónyeréses mutációk következtében az@etoglutarát ( $\alpha \mathrm{KG}$ ) helyett 2-hydroxyglutarát (2-HG), egyonkometabolit képződik [3]. A 2-HG szerkezetileg hasonlít az aKG-ra, és az aKG-függő enzimek [pl. Tet metilcitozin dioxigenáz 2 (TET2), Jumonjitípusú hiszton-demetilázok] kompetitív gátlását idézi elő. A TET2 a DNS 5-metilcitozin nukleotidjainak 5-hidroximetilcitozin átalakulását katalizálja, amely a demetiláció egyik meghatározó lépése $[4,5]$, míg a hiszton demetilázok a hisztonmolekulák lizinjeiről képesek metilcsoportokat hasítani, és így a kromatinszerkezetet módosítani. IDH1-és IDH2-, illetve TET2-mutációk ugyanabban a betegben együtt nagyon ritkán fordulnak elő, mivel ugyanazzal a hatásmechanizmussal rendelkeznek [6, 7]. A TET2 gátlása DNS-hipermetilációt okoz, ami a transzkripciós faktorok [pl. CCAAT/enhancer-binding protein alpha (CEBPA), Runt-related transcription factor 1 (RUNX1), GATA-binding factor 1 (GATA1)] átírásának gátlása révén eredményezi a hematopoietikus sejtek differenciációs blokkját [8,9]. Az IDH1- és IDH2-mutáció következtében keletkező 2-HG a citokróm C oxidáz (COX) aktivitását is gátolja a mitokondriális elektronátviteli láncban, amely a B-sej CD/lymphoma (BCL-2) gátlására érzékenyíti az IDH1- és IDH2-mutáns sejteket [10].

Az IDH1- és az IDH2-mutációk szolid tumorokban és hematológiai kórképekben egyaránt előfordulnak. A mutációk myeloproliferatív neopláziában (MPN) és myelodiszpláziás szindrómában (MDS) ritkák (mintegy 5\%). Az MPN leukémiás transzformációja esetén gyakoriságuk elérheti a $20 \%$-ot $[6,11,12]$. IDH1-mutáció akut myeloid leukémia (AML) 7-14\%-ában figyelhető meg, az esetek nagy részében arginin-cisztein- vagy arginin-hisztidincserét eredményez a 132-es pozícióban (R132C vagy $\mathrm{R} 132 \mathrm{H})$, de ritkább nukleotidcserék is létrejönnek (R132S, R132P, R132G vagy R132L) [13-15]. Az IDH2mutáció gyakoribb AML-ben (8-19\%), és két arginint 
érinthet $[13,14]$. A 140-es pozícióban az arginint glutamin helyettesíti (R140Q), a 172-es pozícióban pedig lizin (R172K) [16].

Az irodalomban nem tisztázott, hogy az IDH1- és IDH2mutációk a leukémiát közvetlenül kiválthatják, vagy már a preleukémiás klónban is jelen vannak, hiszen kis százalékban ugyan, de MDS-ben és MPN-ben is előfordulnak. Papaemmanuil et al. szerint az IDH1-mutációk [az epigenetikai módosításokért felelős TET2-, DNS (citozin-5)-metiltranszferáz 3A (DNMT3A) mutációkhoz hasonlóan], legtöbbször már a nucleophosmin 1 (NPM1) mutáció kialakulása előtt, az akut leukémiás fenotípus megjelenését megelőzően alakulnak ki. Eredményeik szerint azonban az IDH2-R172K-mutált betegek az AML egy külön alcsoportját képezik. Az IDH2-R172K jól elkülöníthető AML génexpressziós és DNS-metilációs profillal társul, és a metabo(11) s aktivitásban súlyosabb aberrációkhoz vezet [17]. Schuurhuis és munkatársai relapszusban a gyakori allélveszteség miatt az IDH1- és IDH2-, illetve az $f m s$-like tirozin kináz-internál tandem duplikáció- (FLT3-ITD-) mutációkat egyedüli markerként nem ajánlják minimális reziduális betegség követésére (MRD), csak kombinációban más markerekkel [18]. Mivel nincsenek egyértelmü irodalmi adatok arra vonatkozóan, hogy az IDH-mutációk a preleukémiás, leukémiakiváltó vagy progresszióért felelős mutációk, ezért tanulmányunkban célul tüztük ki az IDH1- és IDH2-mutációk gyakoriságának felmérését, a különböző mutáció társulások feltérképezését, illetve stabilitásának vizsgálatát relapszuskor.

\section{Módszer}

\section{Betegcsoport}

A tanulmányban 2001. január és 2018. május között a Dél-pesti Centrumkórház - Országos Hematológiai és Infektológiai Intézet, Hematológiai és Őssejt-transzplantációs Osztályán (korábban OHII, OGYK, ESZSZK) diagnosztizált és kezelt 748 AML-ben szenvedő beteg vett részt. A betegek 48,5\%-a $(n=363)$ férfi és $51,5 \%$-a $(n=385)$ nő, az átlagéletkor 50,0 $\pm 15,8$ év (tartomány: 18-93 év) volt a diagnózis időpontjában. A vizsgált csoportban 615 esetben állt rendelkezésünkre citogenetikai eredmény. Az Európai Leukémia Net (ELN) ajánlása szerint a citogenetikai szempontból kedvező prognózisú csoportba a betegek $18,0 \%$-a $(n=111)$; az intermedier csoportba $57,2 \%$-a $(n=352)$ míg a kedvezőtlen csoportba $24,7 \%$-a $(n=152)$ tartozott. A betegek 42,6\%-a $(n=262)$ normál kariotípusú (NK) volt. NPM1 eredmény 745 [ennek 28,3\%-a $(n=211)$ pozitív], FLT3-ITD 747 [amelyből $24,1 \%(n=180)$ pozitív], és tirozin kináz domén mutáció (FLT3-TKD) 734 [ebből 7,6\% $(n=56)$ pozitív] betegnél állt rendelkezésre. IDH1-mutáció tekintetében 106, míg IDH2-mutáció esetén 114 diagnózisrelapszus minta pár volt elérhető. Az adatok gyüjtése retrospektív módon történt. A 2001-2009 között diagnosz- tizált betegek adatai csoportunk egy korábbi közleményében már ismertetésre kerültek [19].

\section{Citogenetikai és molekuláris genetikai módszerek}

A kromoszómaanalízis és a fluoreszcens (nitu hibridizáció (FISH) a standard citogenetikai laboracoriumi eljárásoknak megfelelően történt. A NPM1- [20] és az FLT3ITD- [21] mutációkat kapilláris elektroforézissel, az FLT3-TKD- [22] mutációt restrikciós fragmenshossz polimorfizmusvizsgálattal végeztük. Az IDH1- és IDH2mutációkat első körben high resolution melting (HRM) módszerrel szürtük LightCycler készüléken (LightCycler 480II, Roche Diagnostics). A szürőmódszer pozitivitását multiplex allélspecifikus polimeráz-láncreakcióval (PCR), valamint IDH1 esetében Sanger-szekvenálással erősítettük meg.

\section{Statisztikai módszerek}

A kategorikus változókat (előfordulási gyakoriságokat különböző alcsoportokban) Fisher-egzakt-teszttel, a folyamatos változókat (életkor AML diagnózisakor) Kruskal-Wallis-próbával hasonlítottuk össze. A $p$ érték <0,05 alatt tekintettük az eltéréseket szignifikánsnak. A statisztikai vizsgálatot SPSS 20 verzióval végeztük.

\section{Eredmények}

A 748 AML beteg $8,6 \%$-a $(n=64)$ IDH1 pozitív és $11 \%$-a $(n=82)$ IDH2 pozitív volt (1. és 2. ábra). Az IDH1- és IDH2-mutációk egy betegnél egyszerre nem fordultak elő (3. ábra).

IDH1-pozitív betegek közül 40,6\% $(n=26)$ R132C, $43,8 \%(n=28) \mathrm{R} 132 \mathrm{H}$, és $15,6 \%(n=10)$ egyéb R132 aminosavcserével járt (R132P, R132S, R132G és R132L). Az IDH1-mutáció az esetek 83,3\%-ában intermedier prognosztikájú kariotípussal társult szemben az IHD1és IDH2-negatív betegek esetén észlelt 50,9\% intermedier kariotípus gyakorisággal $(p<0,001)$. Az IDH1-pozitív AML-ben az esetek 58,3\%-a $(n=28)$ NK-val, illetve $25 \%$-a $(n=12)$ egyéb intermedier rizikójú kariotípussal együtt fordult elő. Molekuláris genetikai markerek közül, az IDH1-mutáció 52,4\%-a ( $n=33)$ NPM1-mutációval társult (összehasonlítva az IDH1- és IDH2-negatív betegek esetén észlelt 24,3\% NPM1 társulási gyakorisággal; $p<$ 0,001) (1. táblázat). Eredményeink szerint az IDH1R132C [15,4\% $(n=4)]$ ritkábban jelentkezik NPM1-pozitivitással, mint az IDH1-R132H [85,7\% $(n=24), p<$ 0,001] (2. táblázat). Az FLT3-ITD- és TKD-mutációk hasonló gyakorisággal fordultak elő IDH1-pozitív és IDH1- és IDH2-negatív betegekben (1. táblázat). Diagnózis-relapszus mintapár 106 esetben állt rendelkezésünkre. Az esetek túlnyomó részében, 96,2\%-ban $(n=102)$ az IDH1-mutáció stabilnak bizonyult, progresszió 0,9\%- 

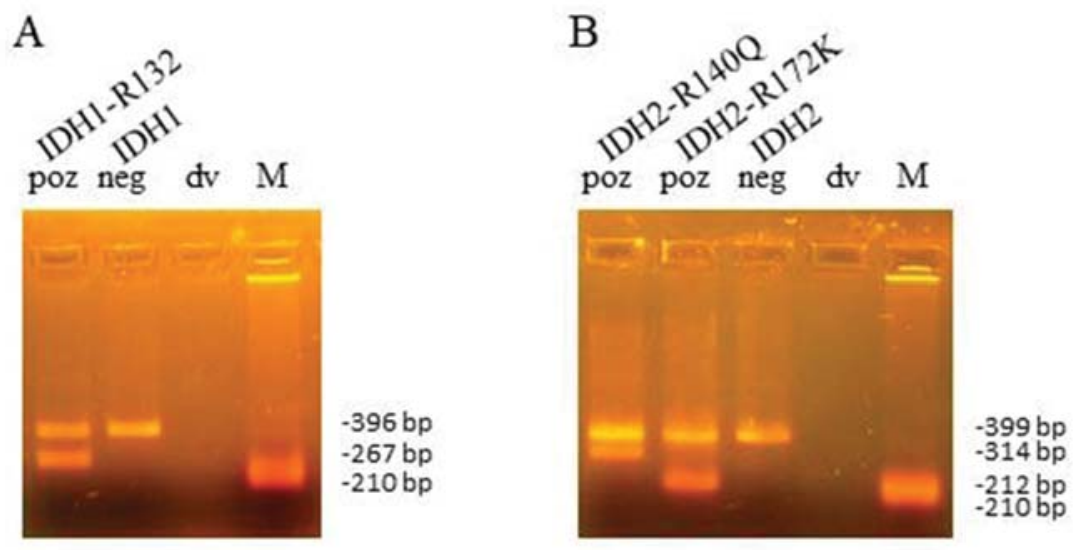

1. ábra. IDH1- és IDH2-mutációk high resolution melting módszerrel történő szűrésének multiplex allélspecifikus polimeráz-láncreakcióval történő megerősítése. Az (A) panelen az IDH1-R132, (B) panelen az IDH2-R140Q és az IDH2-R172K vizsgálata látható. Ábrajegyzék: dv: desztillált víz; IDH1: izocitrát-dehidrogenáz 1; IDH2: izocitrátdehidrogenáz 2; M: méret marker (210 bp); neg: negatív; poz: pozitív

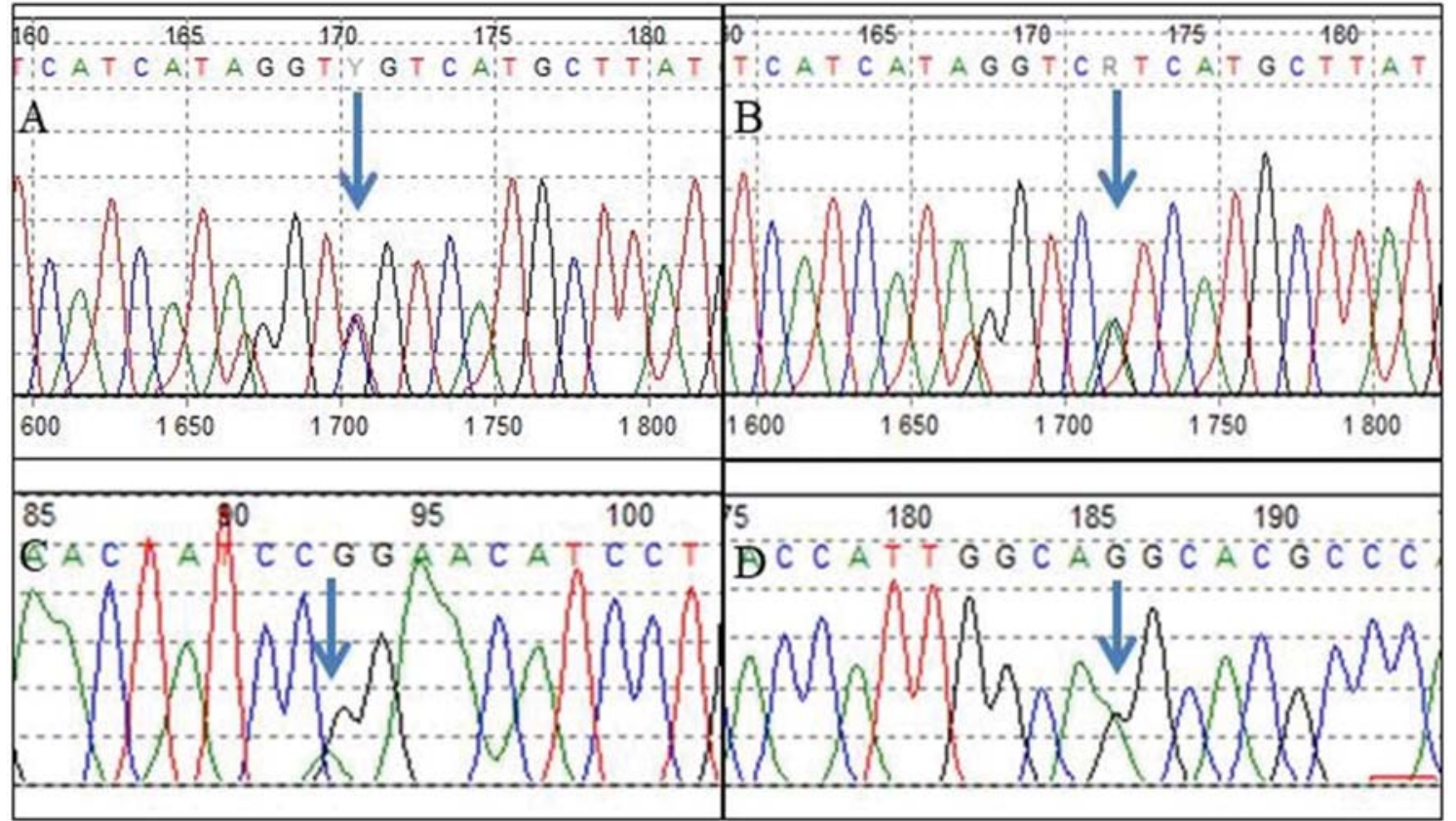

2. ábra. Az IDH1- és az IDH2-mutációk Sanger-szekvenálása. Az (A) panelen az IDH1-R132C- (c.394C>T) mutáció, a (B) panelen az IDH1-R132H (c.395G>A) látható. A (C) panelen IDH2-140Q- (c.419G>A), míg a (D) ábrán IDH2$172 \mathrm{~K}-(\mathrm{c} .515 \mathrm{G}>\mathrm{A})$ mutációk vannak feltüntetve. A nyilak a mutáció pozíciójára mutatnak minden panelen

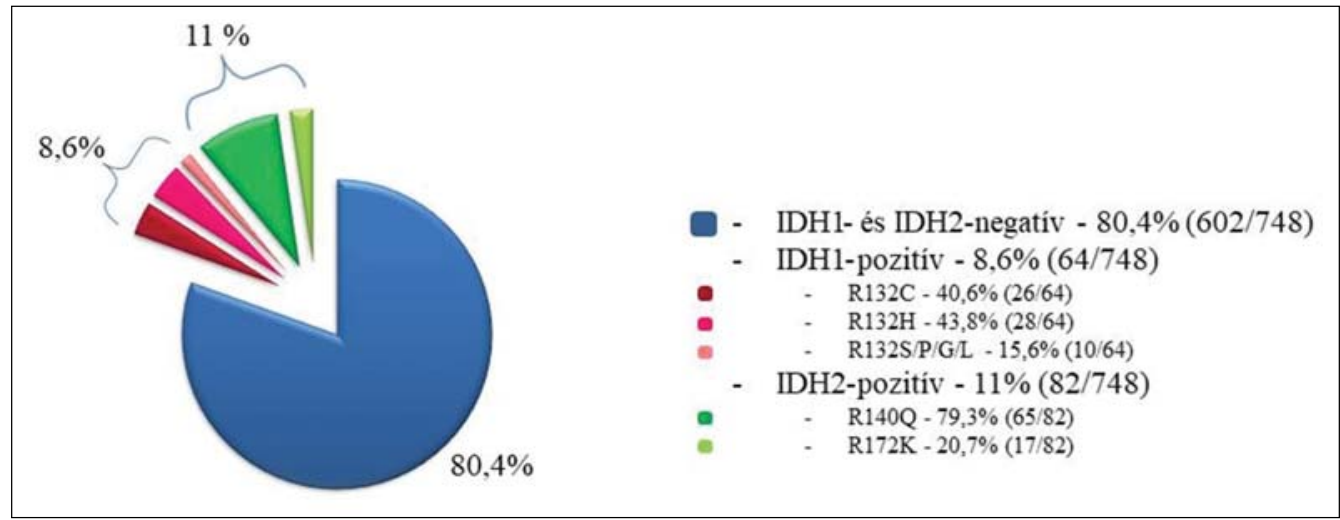

3. ábra. A teljes AML betegcsoport IDH1- és IDH2-mutáció státusza. A betegek 80,4\%-a IDH1- és IDH2negatív, 8,6\%-a IDH1-, 11\%-a IDH2-pozitív 
1. táblázat. Az IDH1-és IDH2-mutációk előfordulása és társulásai citogenetikai és molekuláris markerekhez. Az IDH1- és IDH2pozitív eseteket a mindkét mutációra negatív mintákkal hasonlítottuk össze

\begin{tabular}{|c|c|c|c|c|c|c|c|}
\hline & & Total & IDH1- és IDH2-neg. & IDH1-poz. & $\mathrm{p}^{1}$ & IDH2-poz. & $\mathrm{p}^{2}$ \\
\hline & $n$ & 748 & 602 & 64 & & 82 & \\
\hline & $\begin{array}{l}\text { Férfi/nő } \\
(\% / \%)\end{array}$ & $\begin{array}{c}363 / 385 \\
(48,5 \% / 51,5 \%)\end{array}$ & $\begin{array}{c}302 / 300 \\
(50,2 \% / 49,8 \%)\end{array}$ & $\begin{array}{c}26 / 38 \\
(40,6 \% / 59,4 \%)\end{array}$ & 0,515 & $\begin{array}{c}35 / 47 \\
(42,7 \% / 57,3 \%)\end{array}$ & 0,019 \\
\hline & $\begin{array}{l}\text { átlag életkor } \\
\text { (év) }\end{array}$ & 50 & 49 & 52 & 0,141 & 54 & 0,386 \\
\hline \multirow{6}{*}{ 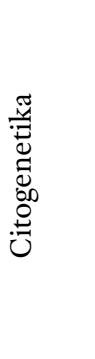 } & kedvező & $111 / 615(18,0 \%)$ & $106 / 501(21,2 \%)$ & $3 / 48(6,3 \%)$ & 0,013 & $2 / 66(3 \%)$ & $<0,001$ \\
\hline & intermedier & $352 / 615(57,2 \%)$ & $255 / 501(50,9 \%)$ & $40 / 48(83,3 \%)$ & $<0,001$ & $57 / 66(86,4 \%)$ & $<0,001$ \\
\hline & $-\mathrm{NK}$ & $262 / 615(42,6 \%)$ & $197 / 501(39,3 \%)$ & $28 / 48(58,3 \%)$ & 0,014 & $37 / 66(56,1 \%)$ & 0,006 \\
\hline & - nem NK & $79 / 615(12,8 \%)$ & $47 / 501(9,4 \%)$ & $12 / 48(25 \%)$ & 0,003 & $17 / 62(27,4 \%)$ & 0,0002 \\
\hline & kedvezőtlen & $152 / 615(24,7 \%)$ & $140 / 501(27,9 \%)$ & $5 / 48(10,4 \%)$ & 0,009 & $7 / 66(10,6 \%)$ & 0,002 \\
\hline & nem ismert & 133 & 101 & 16 & & 16 & \\
\hline \multirow{3}{*}{ 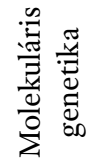 } & NPM1 & $211 / 745(28,3 \%)$ & $146 / 600(24,3 \%)$ & $33 / 63(52,4 \%)$ & $<0,001$ & $32 / 82(39 \%)$ & $<0,001$ \\
\hline & FLT3-ITD & $180 / 747(24,1 \%)$ & $150 / 601(25 \%)$ & $13 / 64(20,3 \%)$ & 0,68 & $17 / 82(20,7 \%)$ & 0,018 \\
\hline & FLT3-TKD & $56 / 734(7,6 \%)$ & $45 / 592(7,6 \%)$ & $7 / 61(11,5 \%)$ & 0,798 & $4 / 81(4,9 \%)$ & 0,29 \\
\hline
\end{tabular}

Rövidítések: FLT3-ITD: fms-like tirozin kináz - internal tandem duplikáció; FLT3-TKD: fms-like tirozin kináz - tirozin kináz domén mutáció; IDH1 és 2: izocitrát dehidrogenáz 1 és 2; $n$ : mintaszám; neg.: negatív; NK: normál kariotípus; NPM1: nucleophosmin1; poz.: pozitív

Megjegyzés: $\mathrm{p}^{1}$ : IDH1-pozitív vs. IDH1-és IDH2-negatív; $\mathrm{p}^{2}$ : IDH2-pozitív vs. IDH1-és IDH2-negatív

ban $(n=1)$, regresszió pedig 2,8\%-ban $(n=3)$ volt megfigyelhetö.

Az IDH2-mutáció 79,3\%-a $(n=65)$ IDH2-R140Q, míg 20,7\%-a ( $n=17)$ IDH2-R172K. Az IDH2 az IDH1-mutációhoz hasonlóan 86,4\%-ban elsősorban intermedier prognosztikájú kariotípussal társult $[\mathrm{NK} 56,1 \%(n=37)$, egyéb intermedier 27,4\% $(n=17)$ ], míg az IHD1- és IDH2-negatív betegek csoportjában az intermedier citogenetikai rizikócsoport az esetek 50,9\%-a $(p<0,001)$. Az IDH2-mutációval rendelkező betegek 39\%-a $(n=32)$ NPM1-mutációval is rendelkezett, szemben az IDH1- és IDH2-negatív betegekkel $(24,3 \% ; p<0,001)$. Az FLT3ITD-mutáció ritkábban fordult elő az összes típusú IDH2-mutációpozitív betegek csoportjában az IDH1- és IDH2-negatívak betegekhez képest (20,7 vs. $25 \%, p=$ 0,018). Az FLT3-TKD-mutáció gyakorisága nem különbözött az IDH2-pozitív, illetve IDH1- és IDH2-negatív betegek esetén (1. táblázat). IDH2 RD0Q-mutációval szemben az IDH2-R172K - bár intermedier prognózisú kariotípussal társult az esetek 94,1\%-ában - ezen belül nem a normál kariotípus dominált [egyéb intermedier $70,6 \%(n=12)$, míg NK 23,5\% $(n=4)]$. Az IDH2-R172K esetekben gyakori volt a 8-as kromoszóma triszómiája. Megfigyeltük, hogy ez a mutáció egyáltalán nem társult NPM1-, sőt FLT3-ITD- és FLT3-TKD-mutációkkal sem (R172K versus R140Q NPM1 társulás: $p=0,001$, FLT3(D)-társulás: $p=0,017$ ) (2. táblázat). Diagnóziskor és relapszuskor 114 beteg mintája volt elérhető. Az IDH2- mutáció 97,4\%-ban $(n=111)$ stabil volt, progresszió 0,9\%-ban $(n=1)$, regresszió $1,8 \%$-ban $(n=2)$ volt látható.

\section{Megbeszélés}

Eredményeink szerint az IDH1- és IDH2-mutációk az AML leggyakoribb genetikai eltérései közé tartoznak (NPM1-, FLT3-, DNMT3A NRAS-, TET2-mutációk mellett). Jelen tanulmányban talált 8,6\% IDH1- és $11,0 \%$ IDH2-mutációs gyakoriság az elmúlt években leírt publikációkhoz hasonlóan alakult (3. táblázat). Az IDH-mutációk leggyakrabban az ELN ajánlás szerinti intermedier rizikócsoportú citogenetikai eltérésekkel, illetve normál kariotípussal társultak. A nem NK csoporton belül főként 8-as kromoszóma triszómiával együtt figyelhetőek meg [23, 24]. Tanulmányunk során hasonló eredményeket figyeltünk meg. Az IDH1- és IDH2-140Q-mutációval rendelkező betegek több mint 50\%-a normál kariotípussal rendelkezett. Megfigyeltük, hogy ezzel ellentétben az IDH2-R172K-mutáns esetek föként intermedier, de nem (1)-sal társultak és a betegek több mint fele 8-as kromoSzoma triszómiával rendelkezett.

Tanulmányok leírták, hogy a NPM1-mutáció IDH1- és IDH2-R140Q-mutációkkal társul, míg IDH2-R172K-val egymást kölcsönösen kizárják [13, 25]. Vizsgálatunk megerősítette azt az álláspontot, hogy az IDH1 és IDH2R140Q NPM1-mutációval társulnak. Esetünkben megfigyeltük, hogy az IDH1-R132H a fó NPM1-mutációval társuló forma. AML betegekben az FLT3-ITD-mutáció 
2. táblázat. Az IDH1-R132C- és IDH1-R132H-, valamint IDH2-R140Q-és IDH2-R172K-mutációk citogenetikai és molekuláris markerekhez való társulásainak az összehasonlítása

\begin{tabular}{|c|c|c|c|c|c|c|c|}
\hline & & & & $\mathrm{p}^{3}$ & & & $\mathrm{p}^{4}$ \\
\hline & & R132C-poz. & R132H-poz. & & R140Q-poz. & R172K-poz. & \\
\hline & $n$ & 26 & 28 & & 65 & 17 & \\
\hline & $\begin{array}{l}\text { Férfi/nő } \\
(\% / \%)\end{array}$ & $\begin{array}{c}11 / 15 \\
(42,3 \% / 57,7 \%)\end{array}$ & $\begin{array}{c}12 / 16 \\
(42,9 \% / 57,1 \%)\end{array}$ & 0,967 & $\begin{array}{c}32 / 33 \\
(49,2 \% / 50,8 \%)\end{array}$ & $\begin{array}{c}3 / 14 \\
(17,6 \% / 82,4 \%)\end{array}$ & 0,019 \\
\hline & $\begin{array}{l}\text { átlag életkor } \\
\text { (év) }\end{array}$ & 56 & 52 & 0,353 & 55 & 52 & 0,386 \\
\hline & kedvező & $1 / 20(5 \%)$ & $2 / 19(10,5)$ & 0,605 & $2 / 49(4,1 \%)$ & $0 / 17(0 \%)$ & 1 \\
\hline & intermedier & $14 / 20(70 \%)$ & $17 / 19(89,5 \%)$ & 0,235 & $41 / 49(83,7 \%)$ & $16 / 17(94,1 \%)$ & 0,428 \\
\hline 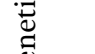 & $-\mathrm{NK}$ & $8 / 20(40 \%)$ & $13 / 19(68,4 \%)$ & 0,111 & $33 / 49(67,3 \%)$ & $4 / 17(23,5 \%)$ & 0,004 \\
\hline .00 & - nem NK & $6 / 20(30 \%)$ & $4 / 19(21,1 \%)$ & 0,716 & $8 / 49(16,3 \%)$ & $12 / 17(70,6 \%)$ & $<0,001$ \\
\hline & kedvezőtlen & $5 / 20(25 \%)$ & $0 / 19(0 \%)$ & 0,047 & $6 / 49(12,2 \%)$ & $1 / 17(5,9 \%)$ & 0,667 \\
\hline & nem ismert & 6 & 9 & & 16 & 0 & \\
\hline$\stackrel{0}{3} \pi$ & NPM1 & $4 / 26(15,4 \%)$ & $24 / 28(85,7 \%)$ & $<0,001$ & $32 / 65(49,2 \%)$ & $0 / 17(0 \%)$ & 0,001 \\
\hline 胥 & FLT3-ITD & $4 / 26(15,4 \%)$ & $7 / 28(25 \%)$ & 0,505 & $17 / 65(26,2 \%)$ & $0 / 17(0 \%)$ & 0,017 \\
\hline$\Sigma$ & FLT3-TKD & $2 / 24(8,3 \%)$ & $4 / 28(14,3 \%)$ & 0,674 & $4 / 64(6,3 \%)$ & $0 / 17(0 \%)$ & 0,574 \\
\hline
\end{tabular}

Rövidítések: FLT3-ITD: fms-like tirozin kináz - internal tandem duplikáció; FLT3-TKD: fms-like tirozin kináz - tirozin kináz domén mutáció; IDH1 és 2: izocitrát dehidrogenáz 1 és $2 ; n$ : mintaszám; neg.: negatív; NK: normál kariotípus; NPM1: nucleophosmin1; poz.: pozitív

Megjegyzés: p³: IDH1-R132C-pozitív vs. IDH1-R132H-pozitív; p": IDH2-R140Q-pozitív vs. IDH2-R172K-pozitív

mintegy 25\%-ban társul IDH-mutációval [26, 27]. Eredményeink szerint az IDH1 20,3\%-ban, az IDH2-R140Q 26,2\%-ban társult FLT3-ITD-mutációval, ami megegyezik az irodalomban leírtakkal. Az IDH2-R172K azonban egyáltalán nem társul FLT3-mutációkkal.

$\mathrm{Az}$ IDH1- és IDH2-mutációk prognosztikai szerepét számos tanulmány vizsgálta, de nem jutottak egyöntetü eredményre [14, 28-33]. A publikációk többségében az IDH1-és IDH2-mutációkat együtt vizsgálták. Az esetlegesen eltérő prognosztikájú IDH-mutációk összevonása mellett a populációs és vizsgálati módszerek különbözősége is okozhatta az eltérő prognosztikai jelentőségre vonatkozó megfigyeléseket. Mégis van olyan tanulmány, amely az IDH2-R172K-t kiemeli viszonylag jobb eredményei miatt, prognosztikai markernek tekinti [14]. Tanulmányunkból is az látszik, hogy míg az IDH1- és IDH2-R140Q-mutációk citogenetikai és molekuláris genetikai markerekhez való társulása hasonló volt, ezzel szemben az IDH2-R172K esetében ezek másképp alakultak.

Az irodalomnak megfelelően mind az IDH1- és IDH2mutáció több mint 96\%-ban stabilnak bizonyult [34, 35]. Néhány esetben azonban progressziót és regressziót figyeltünk meg. Ebből arra következtetünk, hogy az IDHmutáció az AML patomechanizmusának egy korai szakaszában alakul ki (preleukémiás vagy leukémiakiváltó).
Az IDH1- és IDH2 Mációpozitív AML kezelésére a szakirodalomban több Kezelési lehetőséget is olvashatunk az általános gyakorlatban használt kemoterápiás indukciós és fenntartó kezelések mellett. Egyes tanulmányok szerint a hypometiláló szerek (HMA) az IDH-mutációval rendelkező AML és MDS betegek esetében hatékonyabbak [36, 37], azonban ezt nem minden tanulmány erősítette meg [38]. A per os kezelésre alkalmas, kis molekulájú IDH-inhibitorok célzott oki terápiát biztosítanak: az enzim aktív részéhez kötődve, csökkentik az a-ketoglutarát 2-hydroxyglutarát átalakulást [39]. A Food and Drug Administration (FDA) által 2017-ben elfogadott IDH2-inhibitor, az enasidenib (AG-221) hatásosnak bizonyult relabált és refrakter $(\mathrm{R} / \mathrm{R})$ AML esetén. A fázis I/II vizsgálatban $176 \mathrm{R} / \mathrm{R}$ AML beteg esetében a teljes válaszadási ráta [overall response rate (ORR)] 40,3\%, a komplett remisszió (CR) 19,3\%, az első válasz eléréséig eltelt átlagos időtartam 1,9 hónap volt [40]. Az IDH1inhibitor, ivosidenib FDA általi befogadásához vezető fázis I vizsgálatában 78 beteg $(78 \% \mathrm{R} / \mathrm{R} \mathrm{AML})$ vett részt, a teljes válaszadási ráta $38,5 \%$ volt, $\mathrm{CR} 17,9 \%$ [41]. További IDH1- és IDH2-inhibitorok (pl. FT-2102 és IDH305) fázis I vizsgálatai még folyamatban vannak. Megemlítendő az AG-881, amely az IDH1- és IDH2-mutációkra egyaránt hat [3]. Más gyógyszerekhez hasonlóan, az IDH1 és IDH2-re célzottan ható, kis molekulájú inhibitorok ellen is kialakulhat rezisztencia (pl. mutáció a 
3. táblázat. Az IDH1- és IDH2-mutációk előfordulási gyakorisága és prognosztikai jelentősége AML-ben irodalmi adatok szerint. Az összefoglaló táblázat a teljesség igénye nélkül készült, csak a legnagyobb (több mint 100 AML beteget feldolgozó) tanulmányokat rögzítettük, ahol mind az IDH1-t, mind az IDH2-t vizsgálták

\begin{tabular}{|c|c|c|c|c|c|c|}
\hline Szerző [Ref.] & $\begin{array}{l}\text { Publikáció } \\
\text { éve }\end{array}$ & Betegszám & $\begin{array}{l}\text { IDH1-mutáció- } \\
\text { poz. }(\%)\end{array}$ & $\begin{array}{l}\text { IDH2-mutáció- } \\
\text { poz. }(\%)\end{array}$ & $\begin{array}{l}\text { IDH1 prognosz- } \\
\text { tikai jelentőség }\end{array}$ & $\begin{array}{l}\text { IDH2 prognosz- } \\
\text { tikai jelentőség }\end{array}$ \\
\hline $\begin{array}{l}\text { Abbas [Blood 116(12): } \\
\text { 212-216] }\end{array}$ & 2010 & 893 & 6,0 & 11,0 & $\downarrow$ & $\downarrow$ \\
\hline $\begin{array}{l}\text { Boissel [J Clin Oncol. } \\
\text { 28(23): 3717-3723] }\end{array}$ & 2010 & 520 & 9,6 & 3,0 & $\downarrow$ & $\downarrow$ \\
\hline $\begin{array}{l}\text { Ley [N Engl J Med. } \\
\text { 363(25): 2424-2433] }\end{array}$ & 2010 & 281 & 8,9 & 7,1 & n. a. & n. a. \\
\hline $\begin{array}{l}\text { Marcucci [J Clin Oncol. } \\
\text { 28(14): 2348-2355] }\end{array}$ & 2010 & 358 & 14,0 & 19,0 & $\downarrow$ & $\downarrow$ \\
\hline $\begin{array}{l}\text { Paschka [J Clin Oncol. } \\
\text { 28(22): 3636-3643] }\end{array}$ & 2010 & 805 & 7,6 & 8,7 & $\downarrow$ NPM1-nal & $\downarrow$ NPM1-nal \\
\hline $\begin{array}{l}\text { Chou [Leukemia 25(2): } \\
\text { 246-253] }\end{array}$ & 2011 & 446 & 6,1 & 12,1 & - & $\uparrow$ \\
\hline $\begin{array}{l}\text { Rockova [Blood 118(4): } \\
\text { 1069-1076] }\end{array}$ & 2011 & 439 & 7,2 & 8,2 & - & - \\
\hline $\begin{array}{l}\text { Shen [Blood 118(20): } \\
5593-5603 \text { ] }\end{array}$ & 2011 & 605 & 9,3 & 9,8 & - & - \\
\hline $\begin{array}{l}\text { Lin [Ann Hematol. 91(4): } \\
\text { 519-525] }\end{array}$ & 2012 & 198 & 2,0 & 5,0 & - & - \\
\hline $\begin{array}{l}\text { Nomdedéu [Leuk Res. } \\
\text { 36(8): 990-997] }\end{array}$ & 2012 & 275 & 13,1 & 10,2 & $\downarrow$ & $\downarrow$ \\
\hline $\begin{array}{l}\text { Patel [N Engl J Med. } \\
\text { 366(12): 1079-1089] }\end{array}$ & 2012 & 657 & 7,0 & 8,1 & $\begin{array}{l}\text { 个PM1-mu- } \\
\text { tációval }\end{array}$ & $\begin{array}{l}\text { 个PM1-mu- } \\
\text { tációval }\end{array}$ \\
\hline $\begin{array}{l}\text { Ravandi [Cancer. } \\
\text { 118(10): 2665-2673] }\end{array}$ & 2012 & 170 & 7,0 & 14,0 & - & - \\
\hline $\begin{array}{l}\text { Koszarska [Leuk Lym- } \\
\text { phoma 54(5): 1028-1035] }\end{array}$ & 2013 & 376 & 8,5 & 7,5 & $\downarrow \mathrm{R} 132 \mathrm{H}$ & - \\
\hline $\begin{array}{l}\text { Willander [Biomark Res. } \\
2: 18 \text { ] }\end{array}$ & 2014 & 189 & 7,9 & 13,8 & - & $\begin{array}{l}\downarrow \mathrm{R} 140 \mathrm{Q} ; \\
\uparrow \mathrm{R} 172 \mathrm{~K}\end{array}$ \\
\hline $\begin{array}{l}\text { Yamaguchi [Eur J Haema- } \\
\text { tol. 92(6): 471-477] }\end{array}$ & 2014 & 233 & 8,6 & 8,2 & $\downarrow$ & $\downarrow$ \\
\hline $\begin{array}{l}\text { DiNardo [Am J Hematol. } \\
\text { 90(8): 732-736] }\end{array}$ & 2015 & 826 & 7,0 & 13,0 & - & - \\
\hline $\begin{array}{l}\text { Ma [Int J Cancer. 137(5): } \\
\text { 1058-1065] }\end{array}$ & 2015 & 320 & 9,7 & 11,9 & $\downarrow$ & - \\
\hline $\begin{array}{l}\text { Molenaar [Leukemia } \\
\text { 29(11): 2134-2142] }\end{array}$ & 2015 & 334 & 8,0 & 10,0 & $\downarrow$ & $\downarrow$ \\
\hline $\begin{array}{l}\text { Parkin [Clin Cancer Res. } \\
\text { 21(9): 2045-2056] }\end{array}$ & 2015 & 103 & 17,0 & 19,0 & $\downarrow$ & - \\
\hline $\begin{array}{l}\text { Wang [PLoS One 10(10): } \\
\text { e0140622] }\end{array}$ & 2015 & 364 & 11,0 & 13,0 & $\downarrow$ & $\downarrow$ \\
\hline $\begin{array}{l}\text { Papaemmanuil [N Engl J } \\
\text { Med. 374(23): 2209-2221] }\end{array}$ & 2016 & 1540 & 7,0 & 10,0 & n. a. & $\uparrow \mathrm{R} 172 \mathrm{~K}$ \\
\hline $\begin{array}{l}\text { Virijevic [Radiol Oncol. } \\
\text { 50(4): 385-393] }\end{array}$ & 2016 & 110 & 7,0 & 15,5 & $\downarrow$ & $\downarrow$ \\
\hline Jelen tanulmány & 2019 & 748 & 8,6 & 11,0 & n. a. & n. a. \\
\hline
\end{tabular}

Röviditések: IDH1 és 2: izocitrát dehidrogenáz 1 és 2; NPM1: nucleophosmin1; R140Q: 140-es arginin glutamin cserével járó mutáció; R172K: 172-es arginin lizin cserével járó mutáció

Megjegyzés: $\downarrow$ : kedvezőtlen prognózis; $\uparrow:$ kedvező prognózis; - : nincs prognosztikai jelentősége;

n. a.: nincs prognosztikai adat 
gyógyszerkötésért felelős aminosavnál, IDH1-IDH2 izotípusváltás, IDH-független klonális evolúció) [42-44]. Megoldás lehetőségét kínálhatja az IDH-inhibitorok kombinált kemoterápiás alkalmazása [45]. Az IDH1- és IDH2-mutáció pozitív AML-érzékeny lehet a kis molekulájú BCL-2-inhibítorra (venetoclax, monoterápiában, HMA kombinációval, illetve cytarabinnal). Egy fázis Ib tanulmányban 100 idős, intenzív kemoterápiában nem részesülő betegen vizsgálták a venetoclax decitabin vagy venetoclax azacitidin kombinációt, az ORR $68 \%$ volt. HMA kombinációval végzett tanulmányban szintén idős, intenzív kemoterápiára nem alkalmas betegek esetén vizsgálták és az IDH-mutált betegek jobban reagáltak, ami a mutáció epigenetikus következményeinek ismeretében nem teljesen váratlan [46]. Érdekes módon megemlíthető, hogy a C-vitamin stimulálja a TET2 katalitikus aktivitását in vitro, és IDH-R132H expresszáló egér csontvelői leukémiamodellben csökkentette a sejtproliferációt és a fehérvérsejtek differenciációjára jellemző gének expresszióját növelte [47].

Összefoglalásképpen elmondhatjuk, hogy az IDH1- és IDH2-mutációk az AML leggyakoribb genetikai eltérései közé tartoznak (1) normál vagy intermeurer prognózisú, de nem normál kariotípussal, illetve NPM1-mutációval. A társulási arányok nagymértékben függnek az érintett IDH géntől és a konkrét aminosav-változásoktól. Az IDH-mutációk stabil jelenléte a diagnózis és relapszus minta párokban a mutáció korai kialakulására utal az AML többlépcsős patomechanizmusában.

Nyilatkozat: A közlemény beküldésre nem került, más folyóiratban még nem jelent meg. A levelező szerző a szerzői útmutatót megismerte, elolvasta.

Anyagi támogatás: A közlemény a Nemzeti Kutatási, Fejlesztési és Innovációs Hivatal NVKP_16-1-2016-0005, az MTA Bolyai János Kutatási Ösztöndíj (BO/00579/17/5, BO/00809/18/8) és az Emberi Erőforrások Minisztériuma ÚNKP-18-4-SE-11 kódszámú Új Nemzeti Kiválóság Programjának támogatásával készült.

Érdekeltségek: A szerzőknek nincsenek érdekeltségeik. Szerzői munkamegosztás: K. P.: adatgyüjtés, molekuláris genetikai vizsgálatok végzése, eredmények értékelése, kézirat megírása; K. A., Á. E. és B. Ad.: citogenetikai vizsgálatok végzése; B. An. és M. N.: molekuláris genetikai vizsgálati eredmények értékelése; D. J., L. N., H. J., L.V., V-N. I., M. G. és R. P.: betegek kezelése és klinikai adatok elemzése; A. H.: vizsgálati eredmények értékelése, kézirat megírása. A kéziratot valamennyi szerző elolvasta és jóváhagyta.

\section{Köszönetnyilvánítás}

A szerzők köszönettel tartoznak, Csekő Zsófia, Haluska Brigitta, Petró Péterné, Suriné Gulyás Judit és Zsidai Ale- xandra asszisztenseknek a molekuláris genetikai vizsgálatok kivitelezéséért, illetve Magdalena Koszarskának és Feczkó Angélának a 2001-2009 közötti adatok feldolgozásáért.

\section{Irodalom}

[1] Clark O, Yen K, Mellinghoff IK. Molecular pathways: Isocitrate dehydrogenase mutations in cancer. Clin Cancer Res. 2016; 22(8): 1837-1842.

[2] Willander K, Falk IJ, Chaireti R, et al. Mutations in the isocitrate dehydrogenase 2 gene and IDH1 SNP 105C $>$ T have a prognostic value in acute myeloid leukemia. Biomark Res. 2014; $2: 18$.

[3] Montalban-Bravo G, DiNardo CD. The role of IDH mutations in acute myeloid leukemia. Future Oncol. 2018; 14(10): 979-993.

[4] Delhommeau F, Dupont S, Della Valle V. et al. Mutation in TET2 in myeloid cancers. N Engl J Med. 2009; 360(22): 2289-2301.

[5] Ito S, D'Alessio AC, Taranova OV, et al. Role of Tet proteins in $5 \mathrm{mC}$ to $5 \mathrm{hmC}$ conversion, ES-cell self-renewal and inner cell mass specification. Nature 2010; 466(7310): 1129-1133.

[6] Figueroa ME, Abdel-Wahab O, Lu C, et al. Leukemic IDH1 and IDH 2 mutations result in a hypermethylation phenotype, disrupt TET2 function, and impair hematopoietic differentiation. Cancer Cell. 2010; 18(6): 553-567.

[7] Platt MY, Fathi AT, Borger DR, et al. Detection of dual IDH1 and IDH2 mutations by targeted next-generation sequencing in acute myeloid leukemia and myelodysplastic syndromes. J Mol Diagn. 2015; 17(6): 661-668.

[8] Losman JA, Looper RE, Koivunen P, et al. (R)-2-hydroxyglutarate is sufficient to promote leukemogenesis and its effects are reversible. Science 2013; 339(6127): 1621-1625.

[9] Xu W, Yang H, Liu Y, et al. Oncometabolite 2-hydroxyglutarate is a competitive inhibitor of alpha-ketoglutarate-dependent dioxygenases. Cancer Cell 2011; 19(1): 17-30.

[10] Chan SM, Thomas D, Corces-Zimmerman MR, et al. Isocitrate dehydrogenase 1 and 2 mutations induce BCL- 2 dependence in acute myeloid leukemia. Nat Med. 2015; 21(2): 178-184.

[11] Abdel-Wahab O, Levine RL. Mutations in epigenetic modifiers in the pathogenesis and therapy of acute myeloid leukemia. Blood 2013; 121(18): 3563-3572.

[12] Pardanani A, Lasho TL, Finke CM, et al. IDH1 and IDH2 mutation analysis in chronic- and blast-phase myeloproliferative neoplasms. Leukemia 2010; 24(6): 1146-1151.

[13] Marcucci G, Maharry K, Wu YZ, et al. IDH1 and IDH2 gene mutations identify novel molecular subsets within de novo cytogenetically normal acute myeloid leukemia: a Cancer and Leukemia Group B study. J Clin Oncol. 2010; 28(14): 2348-2355.

[14] Papaemmanuil E, Gerstung M, Bullinger L, et al. Genomic classification and prognosis in acute myeloid leukemia. N Engl J Med. 2016; 374(23): 2209-2221.

[15] Wagner K, Damm F, Gohring G, et al. Impact of IDH1 R132 mutations and an IDH1 single nucleotide polymorphism in cytogenetically normal acute myeloid leukemia: SNP rs11554137 is an adverse prognostic factor. J Clin Oncol. 2010; 28(14): 2356-2364.

[16] Molenaar RJ, Thota S, Nagata Y, et al. Clinical and biological implications of ancestral and non-ancestral IDH1 and IDH2 mutations in myeloid neoplasms. Leukemi. 2015; 29(11): 2134-2142.

[17] Chen C, Liu Y, Lu C, et al. Cancer-associated IDH2 mutants drive an acute myeloid leukemia that is susceptible to Brd4 inhibition. Genes Dev. 2013; 27(18): 1974-1985.

[18] Schuurhuis GJ, Heuser M, Freeman S, et al. Minimal/measurable residual disease in AML: a consensus document from the European LeukemiaNet MRD Working Party. Blood 2018; 131(12): 1275-1291.

[19] Koszarska M, Bors A, Feczko A, et al. Type and location of isocitrate dehydrogenase mutations influence clinical characteristics 
and disease outcome of acute myeloid leukemia. Leuk Lymphoma 2013; 54(5): 1028-1035.

[20] Thiede C, Koch S, Creutzig E, et al. Prevalence and prognostic impact of NPM1 mutations in 1485 adult patients with acute myeloid leukemia (AML). Blood 2006; 107(10): 4011-4020.

[21] Kottaridis PD, Gale RE, Frew ME, et al. The presence of a FLT3 internal tandem duplication in patients with acute myeloid leukemia (AML) adds important prognostic information to cytogenetic risk group and response to the first cycle of chemotherapy: analysis of 854 patients from the United Kingdom Medical Research Council AML 10 and 12 trials. Blood 2001; 98(6): 17521759 .

[22] Kottaridis PD, Gale RE, Langabeer SE, et al. Studies of FLT3 mutations in paired presentation and relapse samples from patients with acute myeloid leukemia: implications for the role of FLT3 mutations in leukemogenesis, minimal residual disease detection, and possible therapy with FLT3 inhibitors. Blood 2002; 100(7): 2393-2398.

[23] Aref S, Kamel Areida el S, Abdel Aaal MF, et al. Prevalence and clinical effect of IDH1 and IDH2 mutations among cytogenetically normal acute myeloid leukemia patients. Clin Lymphoma Myeloma Leuk. 2015; 15(9): 550-555.

[24] Ley TJ, Miller C, Ding L, et al. Genomic and epigenomic landscapes of adult de novo acute myeloid leukemia. N Engl J Med. 2013; 368(22): 2059-2074.

[25] Janin M, Mylonas E, Saada V, et al. Serum 2-hydroxyglutarate production in IDH1- and IDH2-mutated de novo acute myeloid leukemia: a study by the Acute Leukemia French Association group. J Clin Oncol. 2014; 32(4): 297-305.

[26] Boddu P, Takahashi K, Pemmaraju N, et al. Influence of IDH on FLT3-ITD status in newly diagnosed AML. Leukemia 2017; 31(11): 2526-2529.

[27] Patel JP, Gonen M, Figueroa ME, et al. Prognostic relevance of integrated genetic profiling in acute myeloid leukemia. $\mathrm{N}$ Engl J Med. 2012; 366(12): 1079-1089.

[28] DiNardo CD, Jabbour E, Ravandi F, et al. IDH1 and IDH2 mutations in myelodysplastic syndromes and role in disease progression. Leukemia 2016; 30(4): 980-4.

[29] DiNardo CD, Ravandi F, Agresta S, et al. Characteristics, clinical outcome, and prognostic significance of IDH mutations in AML. Am J Hematol. 2015; 90(8): 732-736.

[30] Fernandez-Mercado M, Yip BH, Pellagatti A, et al. Mutation patterns of 16 genes in primary and secondary acute myeloid leukemia (AML) with normal cytogenetics. PLoS One. 2012; 7(8): e42334.

[31] Metzeler KH, Herold T, Rothenberg-Thurley M, et al. Spectrum and prognostic relevance of driver gene mutations in acute myeloid leukemia. Blood 2016; 128(5): 686-698.

[32] Virijevic M, Karan-Djurasevic T, Marjanovic I, et al. Somatic mutations of isocitrate dehydrogenases 1 and 2 are prognostic and follow-up markers in patients with acute myeloid leukaemia with normal karyotype. Radiol Oncol. 2016; 50(4): 385-393.
[33] Xu Q, Li Y, Lv N, et al. Correlation between isocitrate dehydrogenase gene aberrations and prognosis of patients with acute myeloid leukemia: A systematic review and meta-analysis. Clin Cancer Res. 2017; 23(15): 4511-4522.

[34] Chou WC, Lei WC, Ko BS, et al. The prognostic impact and stability of Isocitrate dehydrogenase 2 mutation in adult patients with acute myeloid leukemia. Leukemia 2011; 25(2): 246-253.

[35] Lin CC, Hou HA, Chou WC, et al. IDH mutations are closely associated with mutations of DNMT3A, ASXL1 and SRSF2 in patients with myelodysplastic syndromes and are stable during disease evolution. Am J Hematol. 2014; 89(2): 137-144.

[36] Emadi A, Faramand R, Carter-Cooper B, et al. Presence of isocitrate dehydrogenase mutations may predict clinical response to hypomethylating agents in patients with acute myeloid leukemia. Am J Hematol. 2015; 90(5): E77-79.

[37] Jin J, Hu C, Yu M, et al. Prognostic value of isocitrate dehydrogenase mutations in myelodysplastic syndromes: a retrospective cohort study and meta-analysis. PLoS One. 2014; 9(6): e100206.

[38] DiNardo CD, Patel KP, Garcia-Manero G. et al. Lack of association of IDH1, IDH2 and DNMT3A mutations with outcome in older patients with acute myeloid leukemia treated with hypomethylating agents. Leuk Lymphoma 2014; 55(8): 1925-1929.

[39] Kernytsky A, Wang F, Hansen E, et al. IDH2 mutation-induced histone and DNA hypermethylation is progressively reversed by small-molecule inhibition. Blood 2015; 125(2): 296-303.

[40] Stein EM, DiNardo CD, Pollyea DA. et al. Enasidenib in mutant IDH2 relapsed or refractory acute myeloid leukemia. Blood 2017; 130(6): 722-731.

[41] DiNardo CD, Stein EM, de Botton S, et al. Durable remissions with ivosidenib in IDH1-mutated relapsed or refractory AML. N Engl J Med. 2018; 378(25): 2386-2398.

[42] Harding JJ, Lowery MA, Shih AH, et al. Isoform switching as a mechanism of acquired resistance to mutant isocitrate dehydrogenase inhibition. Cancer Discov. 2018; 8(12): 1540-1547.

[43] Intlekofer AM, Shih AH, Wang B, et al. Acquired resistance to IDH inhibition through trans or cis dimer-interface mutations. Nature 2018; 559(7712): 125-129.

[44] Quek L, David MD, Kennedy A, et al. Clonal heterogeneity of acute myeloid leukemia treated with the IDH2 inhibitor enasidenib. Nat Med. 2018; 24(8): 1167-1177.

[45] Nassereddine S, Lap CJ, Tabbara IA. Evaluating ivosidenib for the treatment of relapsed/refractory AML: design, development, and place in therapy. Onco Targets Ther. 2019; 12: 303-308.

[46] DiNardo CD, Pratz KW, Letai A, et al. Safety and preliminary efficacy of venetoclax with decitabine or azacitidine in elderly patients with previously untreated acute myeloid leukaemia: a nonrandomised, open-label, phase 1b study. Lancet Oncol. 2018; 19(2): 216-228.

[47] Mingay M, Chaturvedi A, Bilenky M, et al. Vitamin C-induced epigenomic remodelling in IDH1 mutant acute myeloid leukaemia. Leukemia 2018; 32(1): 11-20. 